\title{
PENENTUAN TIPE FLUIDA, GEOTERMOMETER RESERVOIR DAN HILANG PANAS ALAMIAH BERDASARKAN ANALISIS DATA GEOKIMIA PANAS BUMI DI KABUPATEN BANJARNEGARA, JAWA TENGAH
}

\section{DETERMINATION OF FLUID TYPE, RESERVOIR GEOTHERMOMETER AND NATURAL HEAT LOSS BASED ON GEOCHEMICAL DATA IN BANJARNEGARA REGENCY, CENTRAL JAVA}

\author{
Chusni Ansori *), Fitria Amalia Wardhani *) \\ *)LIPI Karangsambung di Kebumen, Jawa Tengah \\ Jl. Karangsambung Km-19, Kebumen \\ Email: ansorich.63@gmail.com
}

\section{SARI}

Kabupaten Banjarnegara memiliki beberapa daerah potensi panas bumi. Manifestasi fluida panas bumi teramati pada sembilan lokasi di Kecamatan Batur, Kecamatan Wanayasa, Kecamatan Kalibening dan Kecamatan Susukan. Penelitian ini dilakukan untuk mengetahui karakter fluida panas bumi, temperatur reservoir dengan melakukan analisis geokimia fluida panas dan analisis kandungan anion-kation. Analisistipe dan asal fluida ditentukan berdasarkan plotting pada ternary diagram $\mathrm{Cl}-$ $\mathrm{HCO}_{3}-\mathrm{SO}_{4}$ dan $\mathrm{Cl}-\mathrm{Li}-\mathrm{B}$. Temperatur reservoir ditentukan berdasarkan perhitungan geotermometer $\mathrm{Na}-$ $\mathrm{K}-\mathrm{Ca}, \mathrm{K}-\mathrm{Na}-\mathrm{Mg}$ dan Na-K,

Berdasarkan hasil analisis, fluida panas bumi bertipe bikarbonat, klorida dan sulfat. fluida panas bumi bersumber langsung dari reservoir ataupun telah berinteraksi dengan batuan sedimen di sekitarnya. Terdapat empat reservoir panas bumi di daerah penelitian. Reservoir-1 terdapat pada bagian selatan Kabupaten Banjarnegara di Desa Gumelem Susukan, suhu reservoir $81^{\circ} \mathrm{C}$, potensi hilang panas alamiah 95,5 KW. Reservoir-2 berada di sekitar Kecamatan Wanayasa dan Kalibening dengan suhu reservoir berkisar $222^{\circ} \mathrm{C}-264^{\circ} \mathrm{C}$, potensi hilang panas alamiahnya $4,691 \mathrm{MW}$. Reservoir -3 berada di Dieng bagian Utara, Kecamatan Batur dengan suhu reservoir sekitar $137^{\circ} \mathrm{C}$, potensi hilang panas alamiahnya 246,4 KW. Reservoir-4 berada di Dieng bagian Selatan Kecamatan Batur dengan suhu reservoir berkisar $334^{\circ} \mathrm{C}-374^{\circ} \mathrm{C}$, potensi hilang panas alamiahnya $26,58 \mathrm{MW}$.

Kata kunci: Banjarnegara, panas bumi, geokimia, tipe fluida, geotermometer, hilang panas

\section{ABSTRACT}

Banjarnegara Regency has several locations of geothermal potential. Geothermal manifestations are observed in 9 locations of Batur, Wanayasa, Kalibening and Susukan Districts. This study aims to characterize the geothermal fluid, reservoir temperature based on fluid geochemistry and anion-cation contents. Origin and type of fluid are analyzed based on data plotting on $\mathrm{Cl}-\mathrm{HCO}_{3}-\mathrm{SO}_{4}$ and $\mathrm{Cl}-\mathrm{Li}-\mathrm{B}$ ternary diagrams. Reservoir temperature is based on $\mathrm{Na}-\mathrm{K}-\mathrm{Ca}, \mathrm{K}-\mathrm{Na}-\mathrm{Mg}$ and $\mathrm{Na}-\mathrm{K}$ geothermometer calculation.

Results showed that the geothermal fluid has bicarbonate, chloride and sulfate types. This fluid is directly originated from the reservoir or has interaction with sedimentary rocks around. There are 4 identified reservoirs in the study area. Reservoir-1 is located in Gumelem Susukan Village of the southern part of Banjarnegara Regency with reservoir temperature of $81^{\circ} \mathrm{C}$, and natural heat loss potential is 95.5 KW. Reservoir-2 is located around Wanayasa and Kalibening Districts with reservoir temperature between $222-264^{\circ} \mathrm{C}$ and natural heat loss potential is $4.691 \mathrm{MW}$. Reservoir-3 is located in the northern part of Dieng in Batur District with reservoir temperature of $137^{\circ} \mathrm{C}$ and natural heat loss potential is $246.4 \mathrm{KW}$. Reservoir-4 is located in the southern part of Dieng in Batur District with reservoir temperature between $334-374^{\circ} \mathrm{C}$ and natural heat loss potential is $26.58 \mathrm{MW}$.

Keywords: Banjarnegara, geothermal, geochemistry, fluid type, geothermometer, heat loss 


\section{PENDAHULUAN}

Panas bumi merupakan energi yang terbentuk sebagai hasil perpindahan panas dari suatu sumber panas ke sekelilingnya yang terjadi secara konduksi dan konveksi. Perpindahan panas secara konduksi terjadi melalui batuan, sedangkan perpindahan panas secara konveksi terjadi karena adanya kontak antara air dengan suatu sumber panas. Panas bumi menghasilkan energi yang bersih (dari polusi) dan berkesinambungan atau dapat diperbarui. Sumberdaya energi panas bumi dapat ditemukan pada air dan batuan panas di dekat permukaan bumi sampai beberapa kilometer di bawah permukaan. Bahkan jauh lebih dalam lagi sampai pada sumber panas yang ekstrim dari batuan yang mencair atau magma. Energi panas bumi tersebut muncul di permukaan dalam berbagai bentuk manifestasi berupa tanah hangat, tanah beruap, mata air panas/hangat, kolam air panas, telaga air panas, fumarol, geyser, kubangan lumpur panas, silika sinter dan batuan teralterasi (Saptadji, 2003).

Air yang muncul di permukaan dapat digunakan untuk mengetahui kondisi bawah permukaan. Kegunaan data hidrokimia untuk tahap prospeksi bermanfaat untuk mendapatkan informasi mengenai : jenis reservoir, suhu reservoir, jenis batuan, besarnya heat flow, area yang mempunyai heat flow tinggi, problem lingkungan, daerah isian, penentuan lokasi sumur eksplorasi.

Kosentrasi dari unsur-unsur juga dapat digunakan untuk memperkirakan temperatur reservoir atau temperatur sumber air di bawah permukaan. Jenis Geotermometer, meliputi :

a) Silika geotermometer

Memperkirakan temperatur suatu sumber air (reservoir) dibawah permukaan bila air permukaannya jenuh dengan kwarsa, dengan persamaan :

$\begin{array}{lrr}\text { - Proses } & \text { pendinginan secara } \\ \text { adiabatik: } & \mathrm{t}\left({ }^{\circ} \mathrm{C}\right)=(1533.5 / 5.7 \mathrm{log} \\ \left.\mathrm{SiO}_{2}\right)-273 & \end{array}$

- Proses pendinginan secara konduktif: $\quad \mathrm{t}\left({ }^{\circ} \mathrm{C}\right)=(1315 / 5.205$ $\left.\log \mathrm{SiO}_{2}\right)-273$

Memperkirakan temperatur suatu sumber air (reservoir) dibawah permukaan bila air permukaannya jenuh dengan Chalcedony : $\mathrm{t}\left({ }^{\circ} \mathrm{C}\right)=$ (1015.1/4.655 log $\left.\mathrm{SiO}_{2}\right)-273$

b) Sodium - potassium (Na-K) Geotermo meter (Saptadji, 2003)

Sangat tepat untuk air jenis-jenis alkaliklorida dengan $\mathrm{pH}$ netral, tidak tepat digunakann bila ada endapan travertine.

- Persamaannya: $\mathrm{t}\left({ }^{\circ} \mathrm{C}\right)=(855.6 / \mathrm{log}$ $(\mathrm{Na} / \mathrm{K})+0.857)-273$

- Persamaan Fournier; $\mathrm{t}\left({ }^{\circ} \mathrm{C}\right)=(1217 /$ $\log (\mathrm{Na} / \mathrm{K})+1.483)-273$

- Persamaan Giggenbach; $\mathrm{t}\left({ }^{\circ} \mathrm{C}\right)=$ $(1390 / \log (\mathrm{Na} / \mathrm{K})+1.75)-273$

c) Sodium - calsium - potassium Geotermometer

Digunakan untuk air yang mengandung Ca cukup banyak dan menghasilkan endapan travertin. - $\mathrm{t}\left({ }^{\circ} \mathrm{C}\right)=[855.6 /\{\log (\mathrm{Na} / \mathrm{K})+\log$
$(\sqrt{\mathrm{Ca} / \mathrm{Na}})+2.24\}-273$

Kabupaten Banjarnegara dikenal dengan keberadaan lapangan panas bumi Dieng yang menghasilkan energi dengan kapasitas terbukti 60 Mwe. Energi tersebut telah diusahakan oleh PT Geo Dipa Energi yang dijual ke PLN serta telah terintegrasi ke sistem jaringan interkoneksi Jawa Madura Bali (Reva Sasistiya, 2008 dalam Pohan,dkk, 2008). Kendala pemanfaatan energi panas bumi tersebut adalah adanya limbah lumpur sekitar 165 ton/bln yang dibuang sebagai tanah urug (Muljani, S; 2013). Lumpur panas bumi tersebut sekitar $50 \%$ mengandung silika amorf yang dapat dimanfaatkan untuk keperluan industri (Riyanto, dkk., 2012). Beberapa penelitian sebelumnya telah dilakukan terutama pada daerah sekitar PLTP Dieng seperti yang dilakukan oleh Layman, dkk. (2002), Ramadhan, dkk. (2013), Pohan, dkk. (2008).

Penelitian ini bertujuan untuk mengetahui karakteristik manifestasi, tipe fluida, 
temperatur reservoir, dan hilang panas alamiah berdasarkan data geokimia mata air panas dan mata air hangat di Kabupaten Banjarnegara Jawa Tengah, terutama di daerah - daerah yang belum dimanfaatkan. Hasil dari penelitian ini diharapkan dapat digunakan sebagai bahan rekomendasi bagi pemerintah daerah untuk memanfaatkan potensi panas bumi di Kab. Banjarnegara baik secara langsung maupun secara tidak langsung.

\section{METODE}

Penelitian lapangan dilakukan dengan mencari lokasi manifestasi panas bumi, pengamatan kondisi geologi, pengukuran suhu, $\mathrm{pH}$, debit mata air serta pengambilan conto air. Pada conto air dilakukan analisis kation-anion di Laboratorium Pusat Sumber Daya Geologi-Bandung pada tahun 2014. Pada hasil analisis laboratorium tersebut dilakukan pengecekan tingkat kesetimbangan ionnya dan analisis menggunakan berbagai diagram ternary Nicholson (1993) dan Gigenbach (1991) dan perkiraan temperatur reservoir dengan berbagai geotermometer panas bumi.

\section{GEOLOGI}

Wilayah Kabupaten Banjarnegara termasuk dalam fisiografi Zona Pegunungan Serayu Selatan, Zona Pegunungan Serayu Utara, sebagian Zona Depresi Jawa yang memisahkan Pegunungan Serayu Utara dengan Serayu Selatan, serta gunungapi Kuarter di sekitar Dieng. Di bagian utara berupa rangkaian pegunungan dengan kelerengan dan lembah yang curam dengan produk batuan gunungapi Kuarter. Pada bagian tengah merupakan dataran dengan lembah Sungai Serayu yang subur. Sedangkan pada bagian selatan merupakan rangkaian pegunungan yang telah mengalami tektonik kuat dengan lereng yang terjal dan curam, zona ini termasuk rangkaian Pegunungan Serayu Selatan (Van Bemmelen, 1949).

Litologi Kabupaten Banjarnegara tersusun oleh kelompok batuan tertua di Pulau Jawa (Pra Tersier) yang terdapat di sekitar perbatasan antara Kebumen dan Banjarnegara. Kemudian ke arah utara stratigrafi batuannya semakin muda. Litologi di daerah ini sangat beragam, mulai dari batuan tektonit, batuan sedimen, batuan gunungapi, batuan terobosan dan aluvial (Condon dkk., 1996). Adapun stratigrafi daerah ini meliputi; Komplek Melang Luk Ulo, Formasi Karangsambung (Teok), Formasi Totogan (Tomf), Anggota Sigugur Formasi Rambatan (Tmrs), Formasi Rambatan (Tmr), Anggota Tuff Formasi Waturanda (Tmwt), Formasi Waturanda (Tmw), Formasi Panosogan (Tmp), Formasi Halang (Tmph), Formasi Kumbang (Tmpk), Anggota Batugamping Formasi Tapak (Tpd), Anggota Breksi Formasi Tapak (Tptb), Formasi Tapak (Tpt), Formasi Kalibiuk (Tpb), Anggota Batupasir Formasi Damar (Tpds), Formasi Damar (Qtd), Anggota lempung Formasi Ligung (Qtlb), Endapan Undak (Qt), Batuan Gunungapi Jembangan (Qj), Endapan Danau dan Alluvium (Qla), Batuan Gunungapi Dieng (Qd), Batuan Terobosan andesit (Tma) dan Diorit (Tmd) (Gambar 1). 


\section{MAKALAH ILMIAH}

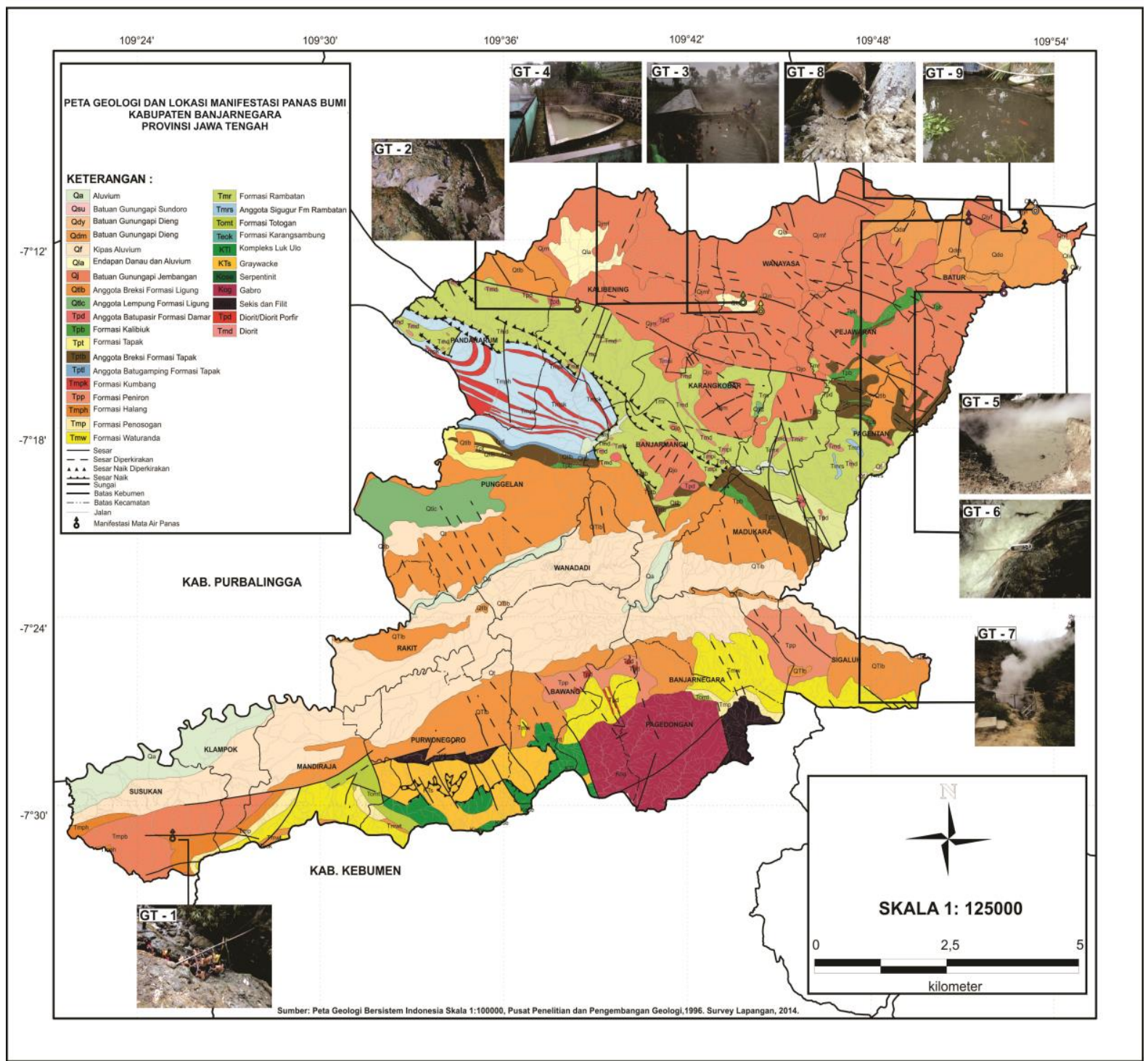

Gambar 1. Peta geologi dan lokasi manifestasi panas bumi di Kabupaten Banjarnegara

(modifikasi dari Peta Geologi Lembar Banjarnegara-Pekalongan, Condon dkk., 1996)

\section{HASIL PENELITAN DAN PEMBAHASAN}

Pengambilan sampel air dilakukan pada sembilan lokasi manifestasi panas bumi di Kabupaten Banjarnegara (Gambar 1). Lokasi sampling tersebut terdapat di Desa Gumelem-Susukan (GT-1), Kalibening (GT-2), Tempuran-Wanayasa (GT-3), Kaliputih-Wanayasa (GT-4), Kawah Sikidang-Batur (GT-5), Pulosari-Batur (GT-6), Kawah Candra Dimuka (GT-7), Kawah Sileri (GT-8) dan Bitingan-Batur (GT-9). Hasil analisis hidrokimia tersebut dapat dilihat pada Tabel 1. Berdasarkan hasil analisis hidrokimia tersebut kemudian dilakukan penghitungan kesetimbangan kation-anion untuk mengecek apakah hasil analisis tersebut bagus atau tidak.

\section{Tipe Fluida panas Bumi}

Berdasarkan ploting pada diagram ternary $\mathrm{Cl}-\mathrm{HCO}_{3}-\mathrm{SO}_{4}$ (Gambar 2), maka tipe fluida panas bumi di Banjarnegara meliputi tipe Klorida (GT-1 dan GT-6), Bikarbonat (GT2, GT-3, GT-4, GT-8 dan GT-9) dan Sulfat (GT-5 dan GT-7). Tipe fluida bikarbonat

(pheripheral water) menandakan adanya percampuran dengan air tanah. Sedangkan chloride water (mature water) manandakan bahwa sumber air berasal dari reservoir, sedangkan sulphate 
water (volcanic water) menandakan bahwa sumber air berkaitan dengan vulkanisme (Nicholson, 1993).

\section{Asal Fluida}

Untuk mengetahui asal fluida panas bumi, maka dilakukan pengeplotan pada diagram ternary Cl-Li-B yang dibuat oleh Giggenbach (1991).
Hasil plot data pada diagram ternary, kandungan relatif $\mathrm{Cl}-\mathrm{Li}-\mathrm{B}$, kandungan $\mathrm{Cl}$ mata air panas pada daerah penelitian mengindikasikan bahwa lokasi GT-1, GT-5, dan GT-6 fluida berasal dari reservoir. Kandungan $\mathrm{B}$ pada manifestasi GT-2, GT-7, GT-8, GT-9 mengindikasikan bahwa fluida telah mengalami interaksi dengan batuan sedimen yang kaya akan zat organik /evaporasi (Nicholson, 1993).

Tabel 1. Hasil analisis hidrokimia manifestasi panas bumi, Kabupaten Banjarnegara

\begin{tabular}{|c|c|c|c|c|c|c|c|c|c|c|}
\hline \multicolumn{2}{|c|}{ Kode Conto } & GT-1 & GT-2 & GT-3 & GT-4 & GT-5 & GT-6 & GT-7 & GT-8 & GT-9 \\
\hline \multicolumn{2}{|l|}{$\mathrm{pH}$} & 8.35 & 7.77 & 7.03 & 9.65 & 2.43 & 6.03 & 7.03 & 7.04 & 7.68 \\
\hline DHL/EC & (umhos/cm) & 3970 & 1459 & 3040 & 3050 & 2260 & 1580 & 2880 & 1041 & 706 \\
\hline TDS & (mg/L) & 4154 & 1164 & 1950 & 2138 & 2060 & 1812 & 1294 & 884 & 722 \\
\hline $\mathrm{SiO}_{2}$ & $(\mathrm{mg} / \mathrm{L})$ & 33.47 & 159.64 & 137.17 & 165.43 & 226.16 & 229.45 & 37.61 & 159.14 & 189.18 \\
\hline B & (mg/L) & 1.14 & 9.65 & 21.11 & 21.36 & 0.02 & 9.04 & 1.78 & 7.55 & 3.17 \\
\hline $\mathrm{Al}^{3+}$ & (mg/L) & 0.01 & 0.01 & 0.01 & 0.01 & 10.75 & 0.01 & 0.01 & 0.08 & 0.01 \\
\hline $\mathrm{Fe}^{3+}$ & $(\mathrm{mg} / \mathrm{L})$ & 0.02 & 0.20 & 3.62 & 0.14 & 51.16 & 0.04 & 1.28 & 0.68 & 0.00 \\
\hline $\mathrm{Ca}^{2+}$ & (mg/L) & 566.01 & 77.25 & 152.11 & 189.74 & 68.13 & 142.17 & 26.38 & 85.27 & 45.40 \\
\hline $\mathrm{Mg}^{2+}$ & (mg/L) & 1.13 & 54.76 & 120.95 & 148.25 & 11.33 & 38.78 & 11.15 & 22.72 & 15.49 \\
\hline $\mathrm{Na}^{+}$ & (mg/L) & 336.61 & 191.30 & 384.18 & 352.92 & 18.58 & 95.79 & 6.18 & 86.36 & 87.45 \\
\hline $\mathrm{K}^{+}$ & $(\mathrm{mg} / \mathrm{L})$ & 2.27 & 31.58 & 40.71 & 41.77 & 10.08 & 64.86 & 3.01 & 25.92 & 35.04 \\
\hline $\mathrm{Li}^{+}$ & (mg/L) & 0.02 & 0.32 & 1.88 & 1.54 & 0.01 & 0.04 & 0.00 & 0.02 & 0.04 \\
\hline $\mathrm{As}^{3+}$ & (mg/L) & 0.00 & 0.00 & 0.00 & 0.00 & 0.00 & 0.00 & 4.00 & 0.00 & 0.00 \\
\hline $\mathrm{NH}_{4}{ }^{+}$ & (mg/L) & 0.60 & 2.90 & 7.60 & 0.60 & 63.00 & 2.70 & 330.00 & 29.00 & 0.20 \\
\hline $\mathrm{F}^{-}$ & (mg/L) & 0.00 & 0.00 & 0.00 & 0.00 & 0.27 & 0.00 & 0.00 & 0.00 & 0.00 \\
\hline $\mathrm{Cl}^{-}$ & (mg/L) & 1412.51 & 86.67 & 639.34 & 538.46 & 2.64 & 426.01 & 4.34 & 26.49 & 10.98 \\
\hline $\mathrm{SO}_{4}{ }^{2-}$ & $(\mathrm{mg} / \mathrm{L})$ & 0.79 & 1.21 & 0.00 & 0.00 & 996.12 & 75.08 & 895.42 & 276.53 & 73.82 \\
\hline $\mathrm{HCO}_{3}-$ & (mg/L) & 16.47 & 885.53 & 982.08 & 1288.90 & 0.00 & 153.76 & 60.66 & 298.79 & 361.45 \\
\hline $\mathrm{CO}_{3}^{-}$ & (mg/L) & 0.00 & 0.00 & 0.00 & 0.00 & 0.00 & 0.00 & 0.00 & 0.00 & 0.00 \\
\hline
\end{tabular}




\section{MAKALAH ILMIAH}

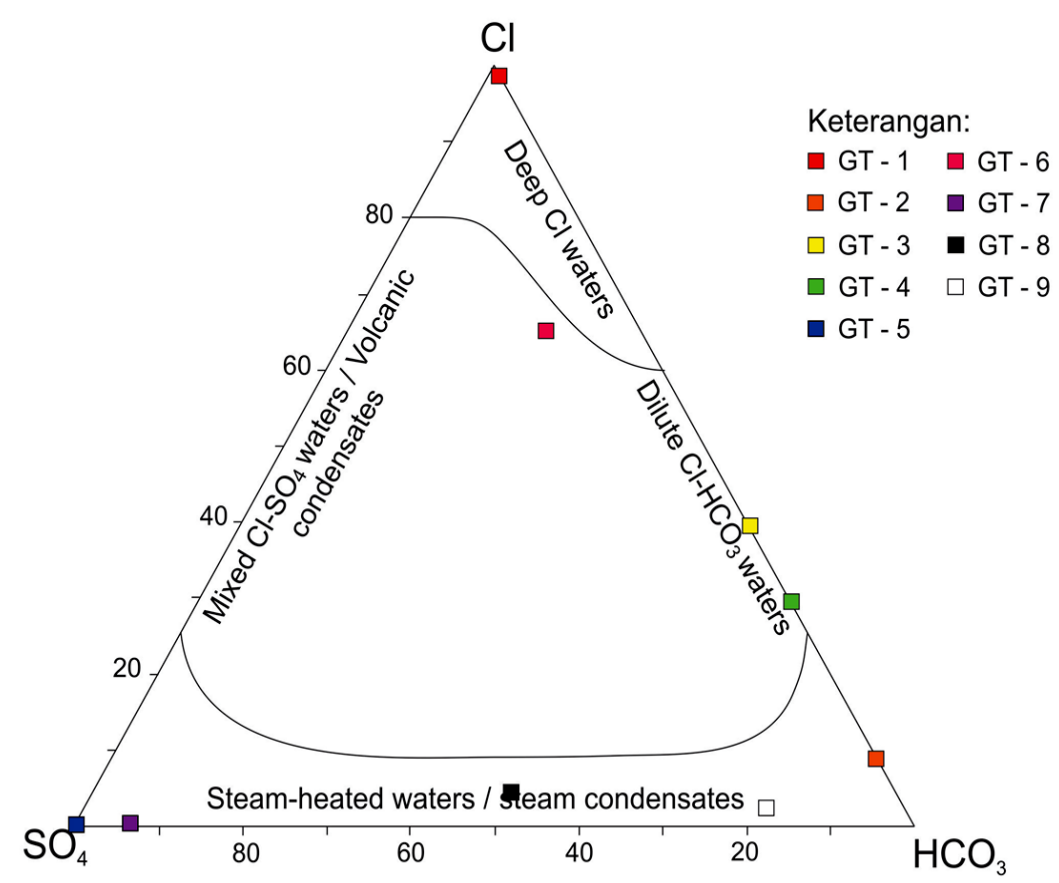

Gambar 2. Diagram ternary $\mathrm{Cl}-\mathrm{HCO}_{3}-\mathrm{SO}_{4}$ untuk menentukan tipe air manifestasi panas bumi (Nicholson, 1993)

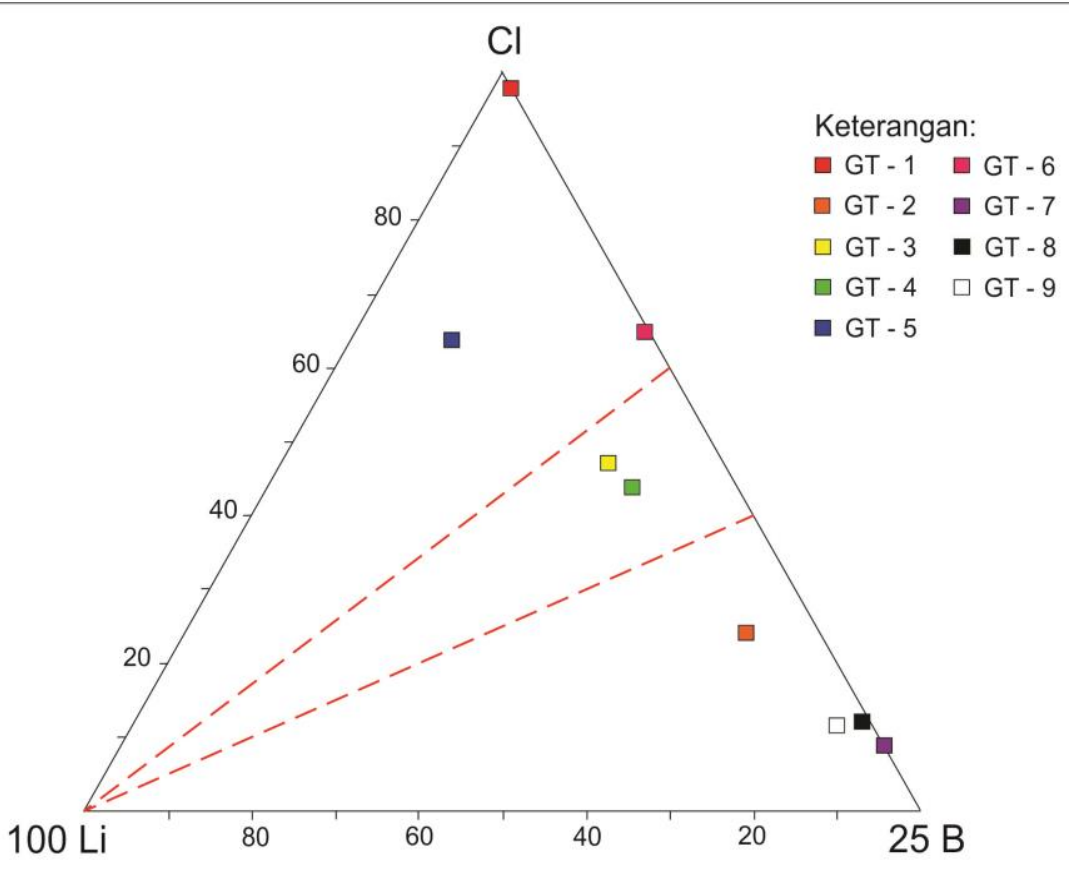

Gambar 3. Diagram ternary untuk menentukan asal fluida panas bumi (Giggenbach, 1991)

Berdasarkan analisis isotop dan geokimia gas pada lapangan panas bumi Dieng maka fluida panas bumi Dieng berasal dari air meteorik yang berinterkasi dengan batuan namun juga ada kontribusi air magmatik terhadap fluida geotermal (Prasetio dkk., 2010). 


\section{Reservoir Panas Bumi}

Penentuan jenis reservoir diinterpretasikan berdasarkan sebaran manifestasi panas bumi, tipe manifestasi, kondisi topografi, tipe fluida panas bumi dan berdasarkan rasio $\mathrm{HCO}_{3} / \mathrm{SO}_{4}$ dan $\mathrm{Cl} / \mathrm{SO}_{4}$. Pada aliran fluida menjauh dari upflow, maka fluida akan memiliki kesempatan yang besar untuk berinteraksi dengan batuan yang dilewati sehingga kemungkinan terjadi peningkatan $\mathrm{HCO}_{3}{ }^{-}$. Hal ini dikombinasi dengan kehilangan $\mathrm{H}_{2} \mathrm{~S}$ karena reaksi airbatuan pada aliran lateral. Dengan demikian kenaikan rasio $\mathrm{HCO}_{3}{ }^{-} / \mathrm{SO}_{4}{ }^{2-}$ mengindikasikan aliran menjauh dari upflow (Nicholson, 1993).

Keluaran yang memiliki nilai rasio $\mathrm{HCO}_{3}{ }^{-}$ $\mathrm{SO}_{4}{ }^{2-}$ rendah dan mengalami kenaikan mengindikasikan arah alirannya bergerak upflow ke outflow (GT-4 ke GT-2, GT 5 ke GT-6, GT-7 ke GT-9). Upflow ditunjukkan oleh kehadiran manifestasi fumarol pada lokasi GT-5 (reservoir 3) dan GT-7 pada reservoir 4. Fluida di reservoir 1 menunjukkan adanya proses pencampuran (dilusi) dengan air tanah yang dicirikan oleh nilai $\mathrm{Cl}$ yang rendah pada rasio $\mathrm{B} / \mathrm{Cl}$.

Sebaran manifestasi GT-1 (Gumelem) berada pada bagian selatan Banjarnegara dan terpisah sangat jauh dengan GT-2 s.d. GT-9. Tipe manifestasi berupa pemunculan air hangat dengan kandungan klorida tinggi (yang menandakan sumber air berasal dari reservoir). Rasio $\mathrm{B} / \mathrm{Cl}=0$ manandakan bahwa manifestasi GT-1 yang bersumber dari air reservoir yang telah mengalami percampuran dengan air tanah dalam perjalannya menuju ke permukaan bumi. Sumber panas (heat source) tidak terkait langsung dengan aktivitas vulkanik, namun diduga berasal dari suatu tubuh intrusi batuan beku yang dalam serta masih menyimpan panas. Dengan dijumpainya lava yang berada di sekitar manifestasi maka tubuh intrusi tersebut tidaklah jauh dari lokasi manifestasi namun pada posisi yang dalam. Anggota breksi Formasi Halang tersusun oleh material vulkanik berupa lava, breksi dan intrusi batuan beku. Oleh karena itu, manifestasi GT-1 merupakan suatu reservoir tersendiri.

\begin{tabular}{|c|c|c|c|c|}
\hline \multirow[t]{2}{*}{ Reservoir } & \multirow[t]{2}{*}{ Kode } & \multicolumn{3}{|c|}{ Perbandingan Unsur (mol \%) } \\
\hline & & $\mathrm{B} / \mathrm{Cl}$ & $\mathrm{HCO}_{3} / \mathrm{SO}_{4}$ & $\mathrm{Cl} / \mathrm{SO}_{4}$ \\
\hline I & GT-1 (Gumelem) & 0.00 & 32.81 & 4835.12 \\
\hline \multirow[t]{3}{*}{ II } & GT-2 (Kalibening) & 0.37 & 1151.75 & 193.70 \\
\hline & GT-3(Tempuran) & 0.11 & 0.00 & 0.00 \\
\hline & GT-4 (Kaliputih) & 0.13 & 0.00 & 0.00 \\
\hline \multirow[t]{2}{*}{ III } & GT-5 (Sikidang) & 0.02 & 0.00 & 0.01 \\
\hline & GT-6 (Pulosari) & 0.07 & 3.22 & 15.34 \\
\hline \multirow[t]{3}{*}{ IV } & GT-7 (Candradimuka) & 1.35 & 0.11 & 0.01 \\
\hline & GT-8 (Sileri) & 0.94 & 1.70 & 0.26 \\
\hline & GT-9 (Bitingan) & 0.95 & 7.71 & 0.40 \\
\hline
\end{tabular}

Manifestasi GT-2, GT-3 dan GT-4 berada pada bagian utara Banjarnegara dengan litologi berupa breksi vulkanik yang termasuk dalam batuan gunung api Jembangan. Secara topografis lokasi GT4 berada pada posisi paling tinggi dengan suhu fluida paling tinggi, sedangkan GT-2 berada pada posisi topografi paling rendah. Ketiga manifestasi menunjukkan tipe fluida yang sama yaitu air bikarbonat, yang menandakan bahwa ketiga manifestasi telah mengalami percampuran dengan air tanah. Berdasarkan nilai rasio $\mathrm{HCO}_{3}{ }^{-} / \mathrm{SO}_{4}{ }^{2}$ (Tabel 2) maka terjadi aliran fluida yang bergerak dari upflow ke outflow (dari lokasi GT-4 ke arah GT-2). 
Berdasarkan data pengukuran Magnetotelurik (MT) yang telah dilakukan tim Geoteknologi LIPI (2013) maka sistem panas bumi di Kecamatan Wanayasa terpisah dengan sistem panas bumi di Kecamatan Batur. Kedua daerah ini dipisahkan oleh patahan di sekitar Jatilawang. Berdasarkan data-data tersebut maka manifestasi GT-2, GT-3 dan GT-4 berasal dari reservoir tersendiri yang terpisah dengan sistem panas bumi di Dataran Tinggi Dieng, Kecamatan Batur.

Manifestasi GT-5 (Sikidang) dan GT-6 (Pulosari) berada di bagian selatan Dataran Tinggi Dieng dengan litologi berupa breksi dari Batuan Gunungapi Dieng. Secara topografi posisi GT-5 lebih tinggi dibanding GT-6, dan pada GT-5 juga menunjukkan adanya Fumarol yang merupakan penanda zona upflow dari sistem panas bumi. Berdasarkan nilai rasio $\mathrm{HCO}_{3}{ }^{-} / \mathrm{SO}_{4}{ }^{2-}$ (Tabel 2) pada GT-6 terjadi peningkatan nilai yang menandakan adanya aliran fluida dari zona up flow lokasi GT-5 menuju zona out flow lokasi GT-6. Tipe fluida pada lokasi GT-5 bersifat sulfat (terkait dengan aktivitas vulkanisme) sedangkan lokasi GT-6 bersifat klorida yang menandakan sumber air berasal dari reservoir. Ramadhan Y, dkk. (2013) mengindikasi kan bahwa manifestasi air panas GT-5 (Sikidang) dengan manifestasi GT-6 (Pulosari) berbeda reservoir. Rasio $\mathrm{B} / \mathrm{Cl}$ Pulosari (GT-6) < 0.01 yang menandakan pengaruh dari proses vulcano-magmatic, sedangkan mata air $(\mathrm{GT}-5) \mathrm{B} / \mathrm{Cl}<0.03$.

Manifestasi di GT-7, GT-8 dan GT-9 berada pada Dataran Tinggi Dieng dengan litologi breksi vulkanik dari Batuan Gunungapi Dieng. Pada lokasi GT-7 (Kawah Candradimuka) terdapat manifestasi fumarol yang merupakan zona up flow dari reservoir IV. Nilai rasio $\mathrm{HCO}_{3}{ }^{-} / \mathrm{SO}_{4}{ }^{2-}$ cenderung meningkat dari lokasi GT-7 ke arah GT-8 dan GT-9 (Tabel 2). Tipe fluida pada lokasi GT-7 merupakan air sulfat dengan suhu tertinggi yang menandakan sumber fluida dari aktivitas vulkanisme, sedangkan pada GT-8 dan GT-9 bersifat bikarbonat yang menandakan adanya percampuran dengan air tanah.

\section{Temperatur Reservoir}

Air panas yang dapat digunakan untuk penghitungan geotermometer atau menghitung temperatur reservoir adalah air panas bertipe klorida ( $\mathrm{Cl})$. Kehadiran klorida mengindikasikan air tersebut langsung bersumber dari reservoir tanpa adanya mixing dengan batuan samping atau fluida lainnya.

Diagram K-Na-Mg (Gambar 4) menggambarkan kesetimbangan fluida panas bumi. Berdasarkan analisis kesetimbangan $\mathrm{K}-\mathrm{Na}-\mathrm{Mg}$ terlihat bahwa hampir semua air panas berada di dekat Mg. Hal ini menunjukkan bahwa air panas bumi tersebut merupakan air immature. Hal ini menjadi salah satu indikasi bahwa meskipun air keluaran bertipe air klorida, yang merupakan air dari reservoir, namun sudah banyak terdilusi dengan air dekat pemukaan

Manifestasi GT-1 dan GT-6 keduanya memiliki kandungan $\mathrm{Cl}$ yang tinggi serta $\mathrm{pH}$ yang netral sehingga dari kedua air ini dapat dilakukan estimasi temperatur reservoir. Geotermometer yang digunakan untuk menghitung temperatur reservoir 1 untuk GT-1 adalah K-Na-Mg dan Na-K-Ca karena manifestasi GT-1 merupakan partial mature dan memiliki kandungan $\mathrm{Ca}$ yang tinggi. Sedangkan untuk reservoir 3 pada manifestasi GT-6 adalah geotermometer $\mathrm{Na}-\mathrm{K}-\mathrm{Ca}$ karena air panas memiliki kandungan $\mathrm{Ca}$ yang tinggi. Formula geotermometer $\mathrm{Na}-\mathrm{K}-\mathrm{Ca}$ dari Fournier (1979) dalam Nicholson (1993) adalah sebagai berikut:

$\mathrm{T}$ Na-K-Ca $\left({ }^{\circ} \mathrm{C}\right)=(1647 /(\log (\mathrm{Na} / \mathrm{K})+$ $[\beta \times \log \sqrt{ }(\mathrm{Ca} / \mathrm{Na})]+2.24))-273$

Berdasarkan perhitungan geotermometer tersebut, reservoir I (lokasi GT-1) memiliki temperatur sekitar $81-174^{\circ} \mathrm{C}$, sedangkan reservoir III sekitar $137{ }^{\circ} \mathrm{C}$, sehingga termasuk tipe reservoir suhu sedang.

Temperatur reservoir II dan IV dihitung 
menggunakan geotermometer $\mathrm{K}-\mathrm{Na}$. Geotermometer ini digunakan dengan mempertimbangkan analisis kimia air mempunyai kesetimbangan ion yang kurang baik. Keuntungan dari geotermometer ini adalah sangat sedikit terpengaruh oleh dilusi. Proses re-equilibriumnya yang lebih lambat ketimbang silika memberikan indikasi bahwa geotermometer ini lebih baik digunakan untuk mengestimasi temperatur dari fluida yang lebih dalam (Karingithi, 2009)..

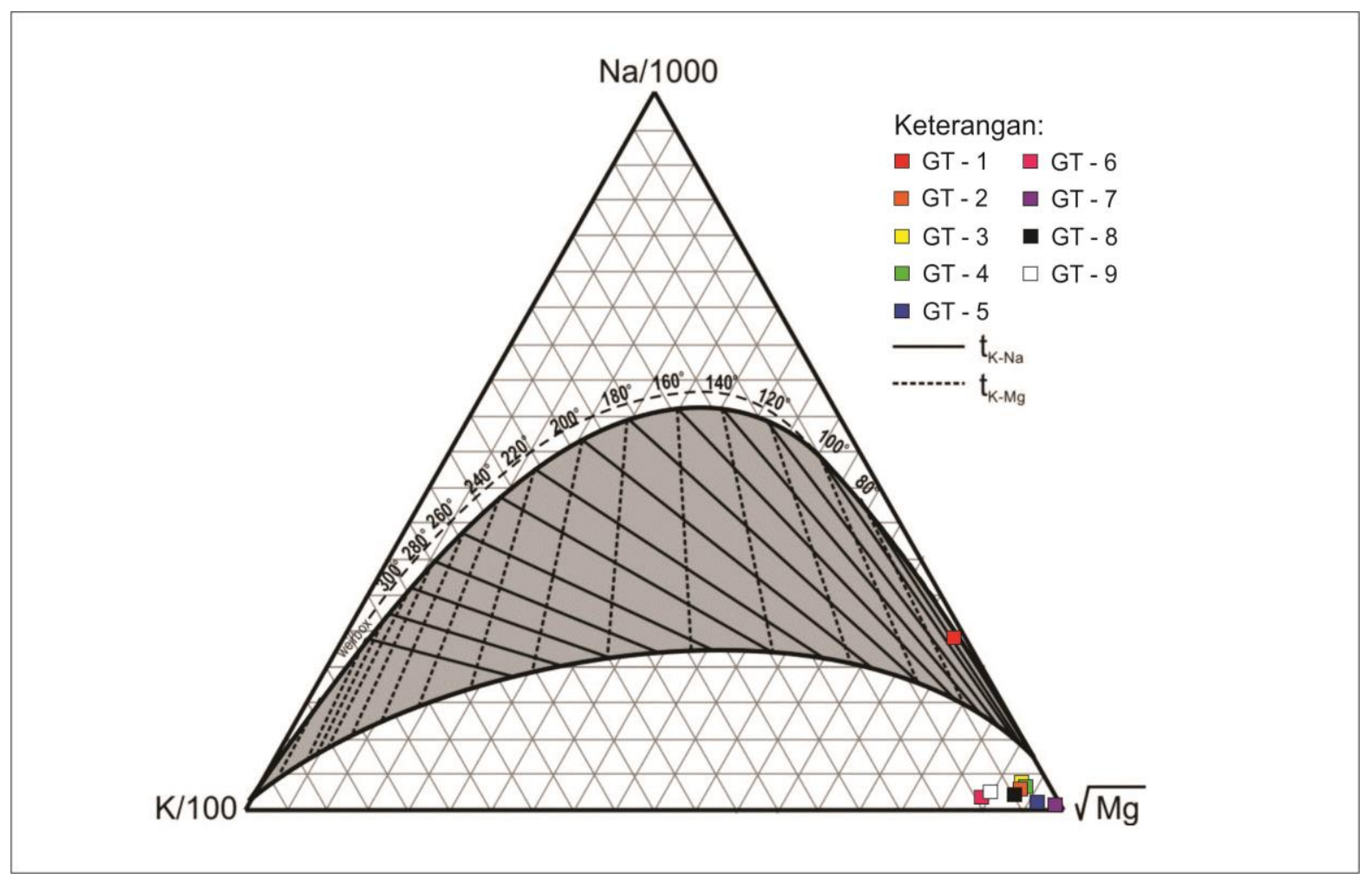

Gambar 4. Diagram ternary $\mathrm{K}, \mathrm{Na}, \mathrm{Mg}$

Tabel 3. Hasil penghitungan geotermometri (Na-K-Ca) dan (K-Na-Mg) No. Reservoir Lokasi $\mathrm{T}(\mathrm{Na}-\mathrm{K}-\mathrm{Ca})\left({ }^{\circ} \mathrm{C}\right) \quad \mathrm{T}(\mathrm{K}-\mathrm{Na}-\mathrm{Mg})\left({ }^{\circ} \mathrm{C}\right)$ Tipe Reservoir

\begin{tabular}{cccccc}
\hline 1 & I & GT-1 & 174 & 81 & Suhu Sedang \\
\hline 2 & III & GT-6 & 137 & - & Suhu Sedang \\
\hline
\end{tabular}

Berdasarkan geotermometer Na-K, reservoir II memiliki temperaturnya sekitar 237-276 ${ }^{\circ} \mathrm{C}$, sedangkan reservoir IV sekitar
374-339 ${ }^{\circ}$, sehingga termasuk reservoir tipe suhu tinggi.

Tabel 4. Hasil penghitungan geotermometri Na-K pada reservoir II dan IV

\begin{tabular}{cccccc}
\hline \multicolumn{5}{c}{ GEOTERMOMETER Na-K } & \multirow{2}{*}{ Tipe Reservoir } \\
\cline { 1 - 5 } No. & Reservoir & Lokasi & $\begin{array}{c}\text { Fournier } \\
(\mathbf{1 9 7 9 )}\end{array}$ & $\begin{array}{c}\text { Giggenbach } \\
(\mathbf{1 9 8 8 )}\end{array}$ & \multirow{2}{*}{ Suhu Tinggi } \\
\hline 1 & II & GT-2 & 264 & 276 & \\
\hline 2 & & GT-3 & 222 & 237 & \multirow{2}{*}{ Suhu Tinggi } \\
\hline 3 & & GT-4 & 232 & 246 & 339 \\
\hline 5 & IV & GT-8 & 334 & 374 & \\
\hline
\end{tabular}




\section{MAKALAH ILMIAH}

Ramadhan dkk (2013) berpendapat bahwa suhu reservoir panas bumi pada Dataran Tinggi Dieng berkisar $225^{\circ} \mathrm{C}$ $295^{\circ} \mathrm{C}$.

\section{Hilang Panas}

Penghitungan hilang panas alamiah (natural heat loss) dalam penentuan potensi panas bumi perlu dilakukan pada keluaran manifestasi panas bumi di daerah penelitian. Hilang panas alamiah ini dihitung berdasarkan rumus yang diberikan oleh Hochstein (1994), yaitu :

$\mathrm{Q}=\mathrm{m} \cdot\left(\mathrm{h}_{\mathrm{fT}}-\mathrm{h}_{\mathrm{fT} 0}\right) \approx \mathrm{m} \cdot \mathrm{c} \cdot\left(\mathrm{T}-\mathrm{T}_{0}\right)$

Keterangan:

$\mathrm{Q} \quad=$ hilang panas $(\mathrm{kJ} /$ detik atau $\mathrm{kW})$ $\mathrm{m} \quad$ = debit massa air panas yang

keluar $(\mathrm{kg} /$ detik $)=\mathrm{V} . \rho \mathrm{r}$

$\mathrm{h}_{\mathrm{fT}}, \mathrm{h}_{\mathrm{fTo}}=$ entalpi fluida $(\mathrm{kJ} / \mathrm{kg})$

$\mathrm{T}=$ temperature mata air panas

$\mathrm{T}_{0} \quad=$ temperature udara rata-rata tahunan

c = kapasitas panas spesifik $(\mathrm{kJ} / \mathrm{kg}$.

${ }^{\circ} \mathrm{C}$ ), c untuk air memiliki nilai rata-rata $=4,2 \mathrm{~kJ} / \mathrm{kg} .{ }^{\circ} \mathrm{C}$ )

Penghitungan hilang panas alamiah disesuaikan dengan tipe manifestasi panas bumi. Rumus di atas dapat digunakan untuk keluaran langsung, yaitu mata air panas atau hangat, aliran air panas, fumarola dan steam yang keluar dari rekahan. Penghitungan hilang panas alamiah akan dilakukan untuk manifestasi bertipe mata air panas dan hangat.

Tabel 5. Penghitungan hilang panas pada masing-masing manifestasi

\begin{tabular}{rrrrrrrr}
\hline \multirow{2}{*}{ No. KodeLokasi } & \multicolumn{6}{c}{ Hilang Panas Bumi Alamiah } \\
& & Debit & C & T udara & T fluida & T (Fluida-udara) & Q (kW) \\
\hline 1 & GT-1 & 1.53 & 4.20 & 27 & 41.9 & 14.90 & 95.55 \\
\hline 2 & GT-2 & 16.75 & 4.20 & 25 & 42.6 & 17.60 & 1238.37 \\
\hline 3 & GT-3 & 50.18 & 4.20 & 24 & 39.5 & 15.50 & 3266.98 \\
\hline 4 & GT-4 & 2.29 & 4.20 & 24 & 43.4 & 19.40 & 186.24 \\
\hline 5 & GT-5 & 0.00 & 4.20 & 18 & 87.2 & 69.20 & 0.00 \\
\hline 6 & GT-6 & 1.57 & 4.20 & 20 & 57.4 & 37.40 & 246.40 \\
\hline 7 & GT-7 & 0.00 & 4.20 & 22 & 84 & 62.00 & 0.00 \\
\hline 8 & GT-8 & 37.46 & 4.20 & 22 & 59.6 & 37.60 & 5915.50 \\
\hline 9 & GT-9 & 115.23 & 4.20 & 22 & 64.7 & 42.70 & 20664.94 \\
\hline & & & & & Total (MW) & 31.61 \\
\hline
\end{tabular}

Tabel 6. Prosentase hasil analisis dalam mol

\begin{tabular}{|c|c|c|c|c|c|c|c|c|c|c|c|c|c|c|c|c|c|c|}
\hline \multirow{4}{*}{ 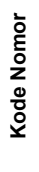 } & \multirow{4}{*}{ Kode } & \multirow{4}{*}{$\mathrm{pH}$} & \multicolumn{15}{|c|}{ DATA KIMIA AIR (mg/kg = mg gas per kg steam) } & \multirow[t]{3}{*}{ TDS } \\
\hline & & & $\mathrm{Ne}$ & & & & & & Kation & & & & & \multicolumn{4}{|c|}{ Anion } & \\
\hline & & & \multicolumn{2}{|c|}{ Satuan mg/L } & \multicolumn{9}{|c|}{ Satuan mg/L } & & Satua & $\mathrm{ng} / \mathrm{L}$ & & \\
\hline & & & $\mathrm{SiO2}$ & B & As3+ & $\mathrm{Li}+$ & $\mathrm{Na}+$ & $\mathrm{K}+$ & $\mathrm{Fe}+$ & Mg2+ & $\mathrm{Ca} 2+$ & $\mathbf{A} \mathbf{l}^{3+}$ & $\mathrm{NH}_{4}^{+}$ & $\mathrm{Cl}-$ & so42- & HCO3- & F- & \\
\hline 1 & GT-1 & 8,35 & 33,47 & 1,14 & 0,00 & 0,02 & 336,61 & 2,27 & 0,02 & 1,13 & 566,01 & 0,01 & 0,60 & 1412,51 & 0,79 & 16,47 & 0,00 & 254 \\
\hline 2 & GT-2 & 7,77 & 159,64 & 9,65 & 0,00 & 0,32 & 191,30 & 31,58 & 0,20 & 54,76 & 77,25 & 0,01 & 2,90 & 86,67 & 1,21 & 885,53 & 0,00 & 102 \\
\hline 3 & GT-3 & 7,03 & 137,17 & 21,11 & 0,00 & 1,88 & 384,18 & 40,71 & 3,62 & 120,95 & 152,11 & 0,01 & 7,60 & 639,34 & 0,00 & 982,08 & 0,00 & 336 \\
\hline 4 & GT-4 & 9,65 & 165,43 & 21,36 & 0,00 & 1,54 & 352,92 & 41,77 & 0,14 & 148,25 & 189,74 & 0,01 & 0,60 & 538,46 & 0,00 & 1288,90 & 0,00 & 304 \\
\hline 5 & GT-5 & 2,43 & 226,16 & 0,02 & 0,00 & 0,01 & 18,58 & 10,08 & 51,16 & 11,33 & 68,13 & 10,75 & 63,00 & 2,64 & 996,12 & 0,00 & 0,27 & 366 \\
\hline 6 & GT-6 & 6,03 & 229,45 & 9,04 & 0,00 & 0,04 & 95,79 & 64,86 & 0,04 & 38,78 & 142,17 & 0,01 & 2,70 & 426,01 & 75,08 & 153,76 & 0,00 & 740 \\
\hline 7 & GT-7 & 7,03 & 37,61 & 1,78 & 4,00 & 0,00 & 6,18 & 3,01 & 1,28 & 11,15 & 26,38 & 0,01 & 330,00 & 4,34 & 895,42 & 60,66 & 0,00 & 936 \\
\hline 8 & GT-8 & 7,04 & 159,14 & 7,55 & 0,00 & 0,02 & 86,36 & 25,92 & 0,68 & 22,72 & 85,27 & 0,08 & 29,00 & 26,49 & 276,53 & 298,79 & 0,00 & 1010 \\
\hline 9 & GT-9 & 7,68 & 189,18 & 3,17 & 0,00 & 0,04 & 87,45 & 35,04 & 0,00 & 15,49 & 45,40 & 0,01 & 0,20 & 10,98 & 73,82 & 361,45 & 0,00 & \\
\hline
\end{tabular}




\section{MAKALAH ILMIAH}

\begin{tabular}{|c|c|c|c|c|c|c|c|c|c|c|c|c|c|c|c|c|c|c|}
\hline \multirow{4}{*}{ 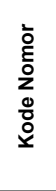 } & \multirow{4}{*}{ Kode } & \multirow{4}{*}{$\mathrm{pH}$} & \multicolumn{15}{|c|}{ DATA KIMIA AIR (mol) ; --> (dibagi Ar/Mr) } & \multirow{4}{*}{ 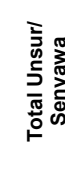 } \\
\hline & & & \multicolumn{3}{|c|}{ Satuan mol } & \multicolumn{8}{|c|}{ Satuan mol } & \multicolumn{4}{|c|}{ Satuan mol } & \\
\hline & & & 60 & 10,8 & 75 & 7 & 23 & 39 & 56 & 24 & 40 & 27 & 15 & 35,5 & 96 & 61 & 19 & \\
\hline & & & $\mathrm{SiO}_{2}$ & B & As & $\mathrm{Li}^{+}$ & $\mathrm{Na}^{+}$ & $\mathrm{K}^{+}$ & $\mathrm{Fe}^{+}$ & $\mathrm{Mg}^{2+}$ & $\mathrm{Ca}^{2+}$ & $\mathrm{Al}^{3+}$ & $\mathrm{NH}_{4}^{+}$ & $\mathrm{Cl}^{-}$ & $\mathrm{SO}_{4}^{2-}$ & $\mathrm{HCO}_{3}{ }^{-}$ & $F^{-}$ & \\
\hline 1 & GT-1 & 8,35 & 0,56 & 0,11 & 0,00 & 0,00 & 14,64 & 0,06 & 0,00 & 0,05 & 14,15 & 0,00 & 0,04 & 39,79 & 0,01 & 0,27 & 0,00 & 69,66 \\
\hline 2 & GT-2 & 7,77 & 2,66 & 0,89 & 0,00 & 0,05 & 8,32 & 0,81 & 0,00 & 2,28 & 1,93 & 0,00 & 0,19 & 2,44 & 0,01 & 14,52 & 0,00 & 34,11 \\
\hline 3 & GT-3 & 7,03 & 2,29 & 1,95 & 0,00 & 0,27 & 16,70 & 1,04 & 0,06 & 5,04 & 3,80 & 0,00 & 0,51 & 18,01 & 0,00 & 16,10 & 0,00 & 65,78 \\
\hline 4 & GT-4 & 9,65 & 2,76 & 1,98 & 0,00 & 0,22 & 15,34 & 1,07 & 0,00 & 6,18 & 4,74 & 0,00 & 0,04 & 15,17 & 0,00 & 21,13 & 0,00 & 68,63 \\
\hline 5 & GT-5 & 2,43 & 3,77 & 0,00 & 0,00 & 0,00 & 0,81 & 0,26 & 0,91 & 0,47 & 1,70 & 0,40 & 4,20 & 0,07 & 10,38 & 0,00 & 0,01 & 22,99 \\
\hline 6 & GT-6 & 6,03 & 3,82 & 0,84 & 0,00 & 0,01 & 4,16 & 1,66 & 0,00 & 1,62 & 3,55 & 0,00 & 0,18 & 12,00 & 0,78 & 2,52 & 0,00 & 31,15 \\
\hline 7 & GT-7 & 7,03 & 0,63 & 0,16 & 0,05 & 0,00 & 0,27 & 0,08 & 0,02 & 0,46 & 0,66 & 0,00 & 22,00 & 0,12 & 9,33 & 0,99 & 0,00 & 34,78 \\
\hline 8 & GT-8 & 7,04 & 2,65 & 0,70 & 0,00 & 0,00 & 3,75 & 0,66 & 0,01 & 0,95 & 2,13 & 0,00 & 1,93 & 0,75 & 2,88 & 4,90 & 0,00 & 21,33 \\
\hline 9 & GT-9 & 7,68 & 3,15 & 0,29 & 0,00 & 0,01 & 3,80 & 0,90 & 0,00 & 0,65 & 1,14 & 0,00 & 0,01 & 0,31 & 0,77 & 5,93 & 0,00 & 16,95 \\
\hline \multirow{3}{*}{ 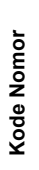 } & \multirow{3}{*}{ Kode } & \multirow{3}{*}{ pH } & \multicolumn{3}{|c|}{$\mathrm{mol} \%$} & \multicolumn{6}{|c|}{$\mathrm{mol} \%$} & & \multicolumn{5}{|c|}{$\mathrm{mol} \%$} & \\
\hline & & & 60 & 10,8 & 75 & 7 & 23 & 39 & 56 & 24 & 40 & 27 & 15 & 35,5 & 96 & 61 & 19 & \\
\hline & & & $\mathrm{SiO}_{2}$ & B & As & $\mathrm{Li}^{+}$ & $\mathrm{Na}^{+}$ & $\mathrm{K}^{+}$ & $\mathrm{Fe}^{+}$ & $\mathrm{Mg}^{2+}$ & $\mathrm{Ca}^{2+}$ & $\mathrm{Al}^{3+}$ & $\mathrm{NH}_{4}{ }^{+}$ & $\mathrm{Cl}^{-}$ & $\mathrm{SO}_{4}{ }^{2-}$ & $\mathrm{HCO}_{3}{ }^{-}$ & $F^{-}$ & \\
\hline 1 & GT-1 & 8,35 & 0,80 & 0,15 & 0,00 & 0,00 & 21,01 & 0,08 & 0,00 & 0,07 & 20,31 & 0,00 & 0,06 & 57,11 & 0,01 & 0,39 & 0,00 & \\
\hline 2 & GT-2 & 7,77 & 7,80 & 2,62 & 0,00 & 0,13 & 24,39 & 2,37 & 0,01 & 6,69 & 5,66 & 0,00 & 0,57 & 7,16 & 0,04 & 42,56 & 0,00 & \\
\hline 3 & GT-3 & 7,03 & 3,48 & 2,97 & 0,00 & 0,41 & 25,39 & 1,59 & 0,10 & 7,66 & 5,78 & 0,00 & 0,77 & 27,38 & 0,00 & 24,48 & 0,00 & \\
\hline 4 & GT-4 & 9,65 & 4,02 & 2,88 & 0,00 & 0,32 & 22,36 & 1,56 & 0,00 & 9,00 & 6,91 & 0,00 & 0,06 & 22,10 & 0,00 & 30,79 & 0,00 & \\
\hline 5 & GT-5 & 2,43 & 16,39 & 0,01 & 0,00 & 0,01 & 3,51 & 1,12 & 3,97 & 2,05 & 7,41 & 1,73 & 18,27 & 0,32 & 45,13 & 0,00 & 0,06 & \\
\hline 6 & GT-6 & 6,03 & 12,28 & 2,69 & 0,00 & 0,02 & 13,37 & 5,34 & 0,00 & 5,19 & 11,41 & 0,00 & 0,58 & 38,53 & 2,51 & 8,09 & 0,00 & \\
\hline 7 & GT-7 & 7,03 & 1,80 & 0,47 & 0,15 & 0,00 & 0,77 & 0,22 & 0,07 & 1,34 & 1,90 & 0,00 & 63,25 & 0,35 & 26,82 & 2,86 & 0,00 & \\
\hline 8 & GT-8 & 7,04 & 12,44 & 3,28 & 0,00 & 0,01 & 17,61 & 3,12 & 0,06 & 4,44 & 10,00 & 0,01 & 9,07 & 3,50 & 13,51 & 22,97 & 0,00 & \\
\hline 9 & GT-9 & 7,68 & 18,60 & 1,73 & 0,00 & 0,03 & 22,43 & 5,30 & 0,00 & 3,81 & 6,70 & 0,00 & 0,08 & 1,82 & 4,54 & 34,96 & 0,00 & \\
\hline
\end{tabular}

Tabel 7. Rasio perbandingan unsur

\begin{tabular}{|c|c|c|c|c|c|c|c|c|c|c|c|c|c|c|}
\hline \multicolumn{2}{|c|}{$\mathrm{mol} \%$} & \multicolumn{9}{|c|}{$\mathrm{mol} \%$} & \multicolumn{4}{|c|}{ mol \% } \\
\hline 60 & 10,8 & 75 & 7 & 23 & 39 & 56 & 24 & 40 & 27 & 15 & 35,5 & 96 & 61 & 19 \\
\hline $\mathrm{SiO} 2$ & B & As & $\mathrm{Li}+$ & $\mathrm{Na}+$ & $\mathrm{K}+$ & $\mathrm{Fe}^{+}$ & Mg2+ & $\mathrm{Ca} 2+$ & $\mathrm{Al} 3+$ & $\mathrm{NH} 4+$ & $\mathrm{Cl}-$ & SO42- & $\mathrm{HCO} 3-$ & F- \\
\hline 0,80 & 0,15 & 0,00 & 0,00 & 21,01 & 0,08 & 0,00 & 0,07 & 20,31 & 0,00 & 0,06 & 57,11 & 0,01 & 0,39 & 0,00 \\
\hline 7,80 & 2,62 & 0,00 & 0,13 & 24,39 & 2,37 & 0,01 & 6,69 & 5,66 & 0,00 & 0,57 & 7,16 & 0,04 & 42,56 & 0,00 \\
\hline 3,48 & 2,97 & 0,00 & 0,41 & 25,39 & 1,59 & 0,10 & 7,66 & 5,78 & 0,00 & 0,77 & 27,38 & 0,00 & 24,48 & 0,00 \\
\hline 4,02 & 2,88 & 0,00 & 0,32 & 22,36 & 1,56 & 0,00 & 9,00 & 6,91 & 0,00 & 0,06 & 22,10 & 0,00 & 30,79 & 0,00 \\
\hline 16,39 & 0,01 & 0,00 & 0,01 & 3,51 & 1,12 & 3,97 & 2,05 & 7,41 & 1,73 & 18,27 & 0,32 & 45,13 & 0,00 & 0,06 \\
\hline 12,28 & 2,69 & 0,00 & 0,02 & 13,37 & 5,34 & 0,00 & 5,19 & 11,41 & 0,00 & 0,58 & 38,53 & 2,51 & 8,09 & 0,00 \\
\hline 1,80 & 0,47 & 0,15 & 0,00 & 0,77 & 0,22 & 0,07 & 1,34 & 1,90 & 0,00 & 63,25 & 0,35 & 26,82 & 2,86 & 0,00 \\
\hline 12,44 & 3,28 & 0,00 & 0,01 & 17,61 & 3,12 & 0,06 & 4,44 & 10,00 & 0,01 & 9,07 & 3,50 & 13,51 & 22,97 & 0,00 \\
\hline 18,60 & 1,73 & 0,00 & 0,03 & 22,43 & 5,30 & 0,00 & 3,81 & 6,70 & 0,00 & 0,08 & 1,82 & 4,54 & 34,96 & 0,00 \\
\hline
\end{tabular}




\section{MAKALAH ILMIAH}

\begin{tabular}{|c|c|c|c|c|c|c|c|c|c|c|c|c|c|}
\hline \multirow{2}{*}{ Kode } & \multirow{2}{*}{ Lokasi } & \multicolumn{12}{|c|}{ Perbandingan Unsur (mol \%) } \\
\hline & & $\mathrm{NH} 4 / \mathrm{B}$ & $\mathrm{Cl} / \mathrm{B}$ & $\mathrm{Na} / \mathrm{K}$ & $B / L i$ & $\mathrm{Cl} / \mathrm{Mg}$ & $\mathrm{Mg} / \mathrm{Ca}$ & $\mathrm{Na} / \mathrm{Mg}$ & $\mathrm{HCO} / \mathrm{SO} 4$ & CL/SO4 & $\mathrm{Na} / \mathrm{Ca}$ & $\mathrm{Cl} / \mathrm{HCO} 3$ & $\mathrm{~B} / \mathrm{Cl}$ \\
\hline 1 & GT-1 & 0,38 & 0,00 & 251,44 & 36,94 & 845,08 & 0,00 & 310,84 & 32,81 & 4835,12 & 1,03 & 147,37 & 0,00 \\
\hline 2 & GT-2 & 0,22 & 0,37 & 10,27 & 19,55 & 1,07 & 1,18 & 3,65 & 1151,75 & 193,70 & 4,31 & 0,17 & 0,37 \\
\hline 3 & GT-3 & 0,26 & 0,11 & 16,00 & 7,28 & 3,57 & 1,33 & 3,31 & 0,00 & 0,00 & 4,39 & 1,12 & 0,11 \\
\hline 4 & GT-4 & 0,02 & 0,13 & 14,33 & 8,99 & 2,46 & 1,30 & 2,48 & 0,00 & 0,00 & 3,23 & 0,72 & 0,13 \\
\hline 5 & GT-5 & 2268,00 & 0,02 & 3,13 & 1,30 & 0,16 & 0,28 & 1,71 & 0,00 & 0,01 & 0,47 & \#DIV/0! & 0,02 \\
\hline 6 & GT-6 & 0,22 & 0,07 & 2,50 & 146,48 & 7,43 & 0,45 & 2,58 & 3,22 & 15,34 & 1,17 & 4,76 & 0,07 \\
\hline 7 & GT-7 & 133,48 & 1,35 & 3,48 & \#DIV/O! & 0,26 & 0,70 & 0,58 & 0,11 & 0,01 & 0,41 & 0,12 & 1,35 \\
\hline 8 & GT-8 & 2,77 & 0,94 & 5,65 & 244,68 & 0,79 & 0,44 & 3,97 & 1,70 & 0,26 & 1,76 & 0,15 & 0,94 \\
\hline 9 & GT-9 & 0,05 & 0,95 & 4,23 & 51,37 & 0,48 & 0,57 & 5,89 & 7,71 & 0,40 & 3,35 & 0,05 & 0,95 \\
\hline
\end{tabular}

Tabel 8. Geotermometer Na-K-Ca

GEOTERMOMETER Na-K-Ca

TOC $=1647 /\{\log (\mathrm{Na} / \mathrm{K})+\mathrm{b}[\log (\mathrm{Ca} 1 / 2 / \mathrm{Na})+2.06]+2.47\}-273$

\begin{tabular}{|c|c|c|c|c|c|c|c|c|c|c|c|}
\hline \multirow[b]{2}{*}{$\dot{\mathbf{z}}$} & \multirow[b]{2}{*}{ 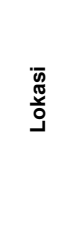 } & \multicolumn{10}{|c|}{$\begin{array}{c}\text { dimana } t>70^{\circ} \mathrm{C} ; b=4 / 3, \text { jika } t<100^{\circ} \mathrm{C} ; b=1 / 3, \text { jika } t>100^{\circ} \mathrm{C} ; \text { jika }[\log (\mathrm{Ca} 1 / 2 / \mathrm{Na})+2.06] \text { bernilai positif } \\
\text { gunakan } b=4 / 3 ; \text { dan } b=1 / 3 \text { jika negatif }\end{array}$} \\
\hline & & $\stackrel{\frac{y}{\pi}}{z}$ & 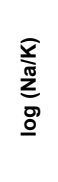 & $\stackrel{\cong}{\pi}$ & $\begin{array}{l}\underset{\mathbb{J}}{\mathbf{N}} \\
\underset{\mathbb{N}}{\mathbb{J}} \\
\underline{U}\end{array}$ & 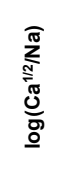 & 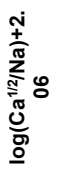 & 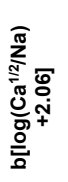 & 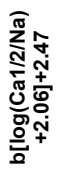 & 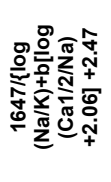 & 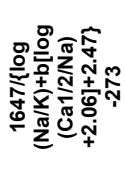 \\
\hline 1 & GT-1 & 148,29 & 2,17 & 23,79 & 0,07 & $-1,15$ & 0,91 & 1,21 & 3,68 & 447,27 & 174,27 \\
\hline 2 & GT-2 & 6,06 & 0,78 & 8,79 & 0,05 & $-1,34$ & 0,72 & 0,96 & 3,43 & 479,76 & 206,76 \\
\hline 3 & GT-3 & 9,44 & 0,97 & 12,33 & 0,03 & $-1,49$ & 0,57 & 0,76 & 3,23 & 510,64 & 237,64 \\
\hline 4 & GT-4 & 8,45 & 0,93 & 13,77 & 0,04 & $-1,41$ & 0,65 & 0,87 & 3,34 & 493,33 & 220,33 \\
\hline 5 & GT-5 & 1,84 & 0,27 & 8,25 & 0,44 & $-0,35$ & 1,71 & 2,28 & 4,75 & 346,97 & 73,97 \\
\hline 6 & GT-6 & 1,48 & 0,17 & 11,92 & 0,12 & $-0,90$ & 1,16 & 1,54 & 4,01 & 410,71 & 137,71 \\
\hline 7 & GT-7 & 2,05 & 0,31 & 5,14 & 0,83 & $-0,08$ & 1,98 & 2,64 & 5,11 & 322,34 & 49,34 \\
\hline 8 & GT-8 & 3,33 & 0,52 & 9,23 & 0,11 & $-0,97$ & 1,09 & 1,45 & 3,92 & 419,93 & 146,93 \\
\hline 9 & GT-9 & 2,50 & 0,40 & 6,74 & 0,08 & $-1,11$ & 0,95 & 1,26 & 3,73 & 441,28 & 168,28 \\
\hline
\end{tabular}

Tabel 9. Geotermometer Na-K

Geotermometer Na-K

Fournier (1979)

Giggenbach (1988)

No. Lokasi $\quad \mathrm{T}^{\circ} \mathrm{C}=(1217 /(\log (\mathrm{Na} / \mathrm{K})+1.483)-273$

$T^{\circ} \mathrm{C}=(1390 /(\log (\mathrm{Na} / \mathrm{K})+1.750)-273$

\begin{tabular}{|c|c|c|c|c|c|c|c|c|c|}
\hline & & $\mathrm{Na} / \mathrm{K}$ & $\underset{(\mathrm{Na} / \mathrm{K})}{\log }$ & $\begin{array}{c}\log \\
(\mathrm{Na} / \mathrm{K})+1.483\end{array}$ & $\begin{array}{c}1217 /(\log \\
(\mathrm{Na} / \mathrm{K})+1.483)\end{array}$ & $\begin{array}{c}(1217 /(\log \\
(\mathrm{Na} / \mathrm{K}))+1.483) \\
-273\end{array}$ & $\underset{(\mathrm{log} / \mathrm{K})+1.750}{ }$ & $\begin{array}{c}1390 /(\log \\
(\mathrm{Na} / \mathrm{K})+1.750)\end{array}$ & $\begin{array}{c}(1390 /(\log \\
(\mathrm{Na} / \mathrm{K}))+1.750) \\
-273\end{array}$ \\
\hline 1 & GT-1 & 148,29 & 2,17 & 3,65 & 333,05 & 60,05 & 3,92 & 354,49 & 81,49 \\
\hline 2 & GT-2 & 6,06 & 0,78 & 2,27 & 537,24 & 264,24 & 2,53 & 548,91 & 275,91 \\
\hline 3 & GT-3 & 9,44 & 0,97 & 2,46 & 495,15 & 222,15 & 2,72 & 510,12 & 237,12 \\
\hline 4 & GT-4 & 8,45 & 0,93 & 2,41 & 505,02 & 232,02 & 2,68 & 519,27 & 246,27 \\
\hline 5 & GT-5 & 1,84 & 0,27 & 1,75 & 695,99 & 422,99 & 2,02 & 689,63 & 416,63 \\
\hline 6 & GT-6 & 1,48 & 0,17 & 1,65 & 736,53 & 463,53 & 1,92 & 724,21 & 451,21 \\
\hline 7 & GT-7 & 2,05 & 0,31 & 1,80 & 677,84 & 404,84 & 2,06 & 673,96 & 400,96 \\
\hline 8 & GT-8 & 3,33 & 0,52 & 2,01 & 606,78 & 333,78 & 2,27 & 611,61 & 338,61 \\
\hline 9 & GT-9 & 2,50 & 0,40 & 1,88 & 647,27 & 374,27 & 2,15 & 647,36 & 374,36 \\
\hline
\end{tabular}


Tabel 10. Geotermometer K-Mg

\begin{tabular}{|c|c|c|c|c|c|c|c|}
\hline \multirow{2}{*}{ No. } & \multirow{2}{*}{ Kode } & \multicolumn{6}{|c|}{$\begin{array}{c}\text { GEOTERMOMETER K-Mg } \\
\mathrm{T}^{\circ} \mathrm{C}=4410 /[14.0-\log (\mathrm{K} 2 / \mathrm{Mg})]-273\end{array}$} \\
\hline & & $\mathrm{K}^{2}$ & $\left(\mathrm{~K}^{2} / \mathrm{Mg}\right)$ & $\log \left(K^{2} / M g\right)$ & $\begin{array}{c}{[14.0-} \\
\left.\log \left(K^{2} / \mathrm{Mg}\right)\right]\end{array}$ & $\begin{array}{l}4410 /[14.0- \\
\left.\log \left(K^{2} / \mathrm{Mg}\right)\right]\end{array}$ & $\begin{array}{c}4410 /[14.0- \\
\left.\log \left(K^{2} / M g\right)\right]-273\end{array}$ \\
\hline 1 & GT-1 & 5,15 & 4,56 & 0,66 & 13,34 & 330,56 & 57,56 \\
\hline 2 & GT-2 & 997,30 & 18,21 & 1,26 & 12,74 & 346,16 & 73,16 \\
\hline 3 & GT-3 & 1657,30 & 13,70 & 1,14 & 12,86 & 342,84 & 69,84 \\
\hline 4 & GT-4 & 1744,73 & 11,77 & 1,07 & 12,93 & 341,09 & 68,09 \\
\hline 5 & GT-5 & 101,61 & 8,97 & 0,95 & 13,05 & 338,00 & 65,00 \\
\hline 6 & GT-6 & 4206,82 & 108,48 & 2,04 & 11,96 & 368,59 & 95,59 \\
\hline 7 & GT-7 & 9,06 & 0,81 & $-0,09$ & 14,09 & 312,98 & 39,98 \\
\hline 8 & GT-8 & 671,85 & 29,57 & 1,47 & 12,53 & 351,98 & 78,98 \\
\hline 9 & GT-9 & 1227,80 & 79,26 & 1,90 & 12,10 & 364,44 & 91,44 \\
\hline
\end{tabular}

\section{KESIMPULAN}

Terdapat tiga jenis tipe fluida di daerah penelitian, yaitu tipe bikarbonat (GT-2, GT3, GT-4, GT-8 dan GT-9), tipe klorida (GT1, GT-6), dan tipe sulfat (GT-5 dan GT-7). Fluida pada lokasi GT-1, GT-5, dan GT-6 berasal dari reservoir; sedangkan fluida GT- 2, GT-7, GT- 8, GT- 9 telah mengalami interaksi dengan batuan sedimen yang kaya akan zat organik. Berdasarkan rasio $\mathrm{HCO}_{3} / \mathrm{SO}_{4}, \mathrm{Cl} / \mathrm{SO}_{4}$ dan $\mathrm{B} / \mathrm{Cl}$, maka reservoir panas bumi di sekitar lokasi manifestasi terdiri dari empat reservoir. Reservoir I, berada di sekitar lokasi GT-1 Desa Gumelem Wetan dengan suhu reservoir $81^{\circ} \mathrm{C}$ (bertipe suhu sedang), hilang panas alamiah 95,5 kW. Reservoir II berada di sekitar GT-2, GT-3, GT-4, Kecamatan Wanayasa dan Kalibening, dengan suhu reservoir berkisar $222^{\circ} \mathrm{C}-264^{\circ} \mathrm{C}$ (suhu tinggi), potensi hilang panas alamiahnya 4,691 MW. Reservoir III berada di sekitar lokasi GT-5, GT-6 di Kecamatan Batur, dengan suhu reservoir berkisar $137^{\circ} \mathrm{C}$ (bertipe suhu sedang), potensi hilang panas alamiahnya 246,4 kW. Reservoir IV berada sekitar lokasi GT-7, GT-8, GT-9 di Kecamatan Batur dengan suhu reservoir berkisar $334-374^{\circ} \mathrm{C}$ (bertipe suhu tinggi), potensi hilang panas alamiahnya 26,58 MW.

\section{UCAPAN TERIMA KASIH}

Ucapan terima kasih disampaikan kepada Kepala Dinas PSDA dan ESDM
Kabupaten Banjarnegara atas ijin dan kesempatan melakukan kegiatan penelitian inventarisasi potensi panas bumi di Kabupaten Banjarnegara.

\section{DAFTAR PUSTAKA}

Bemmelen Van, R.W., 1949. The Geology of Indonesia. Vol.1A. The Hague, Government Printing Office, Jakarta.

Condon W.H., Pardiyanto L., Ketner K.R., Amin T.C., Gafoer S., and Samodra H., 1996. Geological Map of Banjarnegara dan Pekalongan Quadrangles, Central Java. Geological Research and Development Centre, Bandung.

Giggenbach, W. F.,1991. Chemical techniques in geothermal exploration. In: Application of Geochemistry in Geothermal Reservoir Development, F. D'Amore (Ed.), UNITAR-UNDP, Rome, pp. 252-270

Karingithi, C W., 2009. Chemical Geothermometers for Geothermal Exploration. Short Course IV on Exploration for Geothermal Resources, organized by UNU-GTP, KenGen and GDC, at Lake Naivasha, Kenya.

Muljani Sri, Setyawan H., Wibawa G., Altway A. ; 2013; Pencucian Dua tahap Untuk Preparasi Silika DariLumpur Panas Bumi; Jurnal Teknik Kimia Vol 7, No2.

Nenny Miryani Saptadji 2001. Teknik Panas Bumi; Departemen 


\section{MAKALAH ILMIAH}

Perminyakan, Fakultas IImu Kebumian dan Teknokoli Mineral, ITB, Bandung.

Nicholson, K.N., 1993. Geothermal Fluids, Chemistry and Exploration Techniques. Springer- Verlag, Berlin Heidelberg, 263pp.

Prasetio R., Abidin Z. , Yulizar Y; 2010. Isotope and Gas Geochemistry of Dieng Geothermal Field, Indonesia; Proceedings World Geothermal Congress, Bali, Indonesia, 25-29 April 2010.

Pohan, Mangara P, Herman Danny Z, R Hutamadi. 2008. Penelitian Mineral Ikutan pada Lapangan Panas Bumi daerah Dieng, Kabupaten Banjarnegara, Provinsi Jawa Tengah. Artikel Pusat Sumberdaya Geologi. Bandung.
Ramadhan.,K. Herdianita , 2013. Hotwater Geochemistry for Interpreting The Condition of Geothermal Reservoir, Dieng Plateau Case, Banjarnegara- Wonosobo Regency, Central Java; Indonesian Journal of Geology, Vol. 8 No. 2 June 2013: 89-96

Riyanto N., Sumardi, Indra Perdana; 2012. Kinetika Pelarutan Silika Amorf dari Lumpur Panas Bumi Dieng; Jurnal Rekayasa Proses, Vol. 6, No. 1, 2012

Layman, E B., Agus, I, dan Warsa, S. 2002. The Dieng Geothermal Resource, Central Java, Indonesia. Procceding Geothermal Resources Council Transactions, Vol. 26, September 22-25.

$\begin{array}{ll}\text { Diterima } & : \text { 20 Agustus } 2015 \\ \text { Direvisi } & : 1 \text { Oktober } 2015 \\ \text { Disetujui } & : 15 \text { November } 2015\end{array}$

